\title{
An approach to the ecological significance of chemically mediated bioactivity in Mediterranean benthic communities
}

\author{
M. J. Uriz ${ }^{1}$, D. Martin ${ }^{1}$, X. Turon ${ }^{1}$, E. Ballesteros ${ }^{1}$, R. Hughes ${ }^{2}$, C. Acebal ${ }^{3}$ \\ ${ }^{1}$ Centre d'Estudis Avançats de Blanes (C.S.I.C.), Camí de Santa Bàrbara s/n, E-17300 Blanes (Girona), Spain \\ ${ }^{2}$ Roswell Park Cancer Institute, 666 Elm Street, Buffalo, New York 14263, USA \\ ${ }^{3}$ Pharma Mar S.A., Calle de la Calera s/n, Tres Cantos, Madrid, Spain
}

\begin{abstract}
Possible ecological roles of antibacterial, antifungal, antiviral, cytotoxic and antimitotic activities found in western Mediterranean benthos were investigated, and relationships were sought between these activities and taxonomic groups, presence of fouling organisms, and community structure. Cytotoxic and antimitotic activities are the most abundant, and are widespread in almost all the taxonomic groups studied. Porifera, Bryozoa and Tunicata contain the most biologically active chemicals. Cytotoxic molecules are more frequently present in tunicates than in bryozoans. There is a close association between antimitotic and cytotoxic, as well as between antibacterial and antifungal, activities. As antifouling defences, cytotoxic and antimitotic activities seem to be less effective than antibacterial and antifungal ones; the latter appear to function in a generalist antifouling mode. Chemically rich species are much more abundant in sciaphilic/cryptic habitats than in photophilic ones.
\end{abstract}

\section{INTRODUCTION}

The production of biologically active substances in benthic organisms has traditionally been related to various aspects of their biology (Stoecker 1978, 1980, Bergquist 1979, Castiello et al. 1979, Bakus 1981, Shanks \& Graham 1988, Munro et al. 1989, Wahl 1989), ecology (Goodbody 1961, Jackson \& Buss 1975, Buss 1976, Green 1977. Sheppard 1979, Coll et al. 1982, Sammarco et al. 1983, 1985. Thompson et al. 1985 , Bakus et al. 1986, Amade et al. 1987, Hay 1988, 1989, Paul \& Van Alstyne 1988, Porter \& Targett 1988), systematics (Cimino et al. 1975, Fenical \& Norris 1975, Bergquist \& Bedford 1978, Bergquist \& Wells 1983, Bergquist et al. 1984, Lee \& Gilchrist 1986, Munro et al. 1989), geographical distribution (Bakus 1974, Bakus \& Green 1974, Bakus et al. 1986, Amade et al. 1987 , McClintock 1987) and evolution (Thompson 1960a, b, Faulkner \& Ghiselin 1983, Hay 1984, Pimentel 1988).

In spite of this extensive literature, many questions still remain on the extent of chemically mediated interactions in benthic communities, and their role in species behavior. Some of the conclusions reported in the literature are even contradictory. Thus, Bakus \& Green (1974) and Green (1977) found a negative corre- lation between toxicity and latitude, while McClintock (1987) subsequently found a higher percentage of active species in the Antarctic region than at lower latitudes. Some authors have reported that the number of active species is higher in cryptic environments than in exposed coral reef ones (Jackson \& Buss 1975), a reflection that allelopathy plays an important role in spatial competition interactions. By contrast Bakus (1981) deduced that these chemical defences are more important on exposed facies where they play an antipredatory role. The situation is clearly not yet resolved and more research into the nature and function of allelopathy in marine communities is required. Two criteria should be present in these studies: firstly, a large number of organisms should be studied, to allow comparisons between communities, biological taxa and geographical areas, and secondly, detailed studies should be carried out on the nature and function of the biologically active metabolites to provide clues to the complex ways in which these substances work. Our research deals with the first of these fields, by means of extensive sampling in different benthic communities.

Chemically mediated bioactivity as an ecological phenomenon has been little studied in the Mediterranean Sea (Amade et al. 1987) in comparison to the 
tropical and temperate Atlantic zones or Pacific regions. In this paper we look for possible ecological roles for the antibacterial, antifungal, antiviral, cytotoxic and antimitotic activities found in western Mediterranean benthos. These activities indicate the presence of biologically active organic molecules in the organisms concerned which may serve an ecological function.

\section{MATERIAL AND METHODS}

Benthic communities. Benthic littoral habitats were classified in this study based in part on work by Pérès \& Picard (1964), Ballesteros (1984), Ros et al. (1984) and Gili \& Ros (1985), to try to combine both botanical and zoological criteria. The following communities or groups of communities were used:

- Communities of photophilic algae (PA): infralittoral communities with photophilic algae, which ranged in the area studied from 0 to $12 \mathrm{~m}$ in depth.

- Communities of sciaphilic algae (SA): infralittoral communities dominated by fleshy algae (Codium, Dictyopteris) with low photophilic affinities (Ballesteros 1984 ), ranging from 10 to $40 \mathrm{~m}$ in depth.

- Precoralligenous (PC). This term is used to describe communities of spatial transition between areas dominated by fleshy sciaphilic algae and the coralligenous community. The presence of more or less calcified algae (Mesophyllum, Halimeda, Peyssonnelia) and a high number of substratum-dependent invertebrates characterize this community.

- Coralligenous blocks, lower side (CBL). This is an aspect of the classic coralligenous community (Pérès \& Picard 1964, Ros et al. 1985), basically including organisms from dark zones of the calcareous algae concretions.

- Coralligenous blocks, upper side (CBU). These habitats receive more light and are more stressed physically than the lower sides of the coralligenous blocks. Accordingly, they bear different populations (Ros et al. 1985). Some algae typical of the precoralligenous level (especially Halimeda tuna) are still present and are sometimes even abundant.

- Semi-obscure caves (SOC). This community is characterized by animal dominance (Pérès \& Picard 1964) and includes caves, deep crevices and large overhangs.

- Habitats under blocks (UB). These include communities under blocks and large boulders, provided there is some degree of stability (due either to the size of the block or the low level of hydrodynamism preventing the blocks from rolling). They are composed of more sciaphilic and generally small-sized, fixed species together with typical vagile invertebrate populations.
- Posidonia oceanica meadows (PM). This community is usually located on soft bottoms, to which it provides stability (Pérès \& Picard 1964), but it can also develop on rocky bottoms. Sciaphilic organisms are found under the plant canopy (Ballesteros et al. 1984).

- Detritic bottoms (DB), made up of gravels and biogenic detritus (shells, algae fragments, etc.) of different sizes. These communities are inhabited by heterogeneous populations adapted to unstable substrata and to high levels of sedimentation.

- Euryhaline and eurythermal lagoons (EEL). This habitat includes different communities inhabiting both hard and soft bottoms (Pérès \& Picard 1964) in shallow waters.

The species tested represent a high percentage of the total biomass in each community, reaching $90 \%$ for some taxonomic groups, such as the sponges and algae.

Sampling. A total of 800 samples were taken by SCUBA diving in October 1988 during the Pharmamar I survey aboard the BO 'García del Cid' (oceanographic vessel of the Spanish Research Council). The zone surveyed and sampled includes the Balearic Archipelago and the Columbretes Islands. The different communities at all 27 sampling stations (Table 1), were sampled exhaustively on vertical transects $4 \mathrm{~m}$ wide. These samples yielded a total of 238 species of benthic algae, phanerogams and invertebrates distributed throughout the 10 groups of communities (Table 2).

Species were identified by taxonomists in situ or on board whenever possible. In other cases, small samples were fixed in $5 \%$ formaldehyde or $70 \%$ alcohol (when it was necessary to preserve some calcareous structures) for later identification.

Data on epibiosis were recorded on every specimen collected. Sampling was done without preferences for fouled or non-fouled specimens.

Screening. Antibacterial and antifungal activities were determined for 226 species, while antiviral, antimitotic and cytotoxic activities were assessed for 214 species. A small portion of each specimen $(2 \mathrm{~g}$ in weight) was homogenized in $20 \mathrm{ml}$ of $3: 1$ methanol/ toluene and centrifuged (Rinehart et al. 1983). Small sterile paper disks, $6 \mathrm{~mm}$ in diameter, were soaked in the test solutions, air-dried and employed in the activity tests. Control tests were performed with the solvent.

The antimicrobial activity of the crude organic extracts was tested by the diffusion method (Bergquist \& Bedford 1978, interpreted following Thompson et al. 1985) on cultures of 2 strains of bacteria, Escherichia coli and Bacillus subtilis, and 2 of fungi, Candida albicans and Aspergillus niger. Antimitotic tests were performed on leukemic cells of mice (L1210) by determining inhibition of cell growth. Antiviral and cytotoxic tests were performed with herpes simplex virus, type I 
Table 1. Sampling stations. PA: photophilic algae; SA: sciaphilic algae; PC: precoralligenous; CBU: coralligenous blocks, upper sides; CBL: coralligenous blocks, lower sides; SOC: semi-obscure caves; UB: under blocks; PM: Posidonia meadows; DB: detritic bottoms; EEL: euryhaline and eurytherm lagoons

\begin{tabular}{|c|c|c|c|c|c|}
\hline Locality & Site & Lat./Long. & Orientation & Depth (m) & Communities \\
\hline \multirow[t]{7}{*}{ Columbretes Is. } & Columbrete Grande & $\begin{array}{r}39^{\circ} 53.8^{\prime} \mathrm{N} \\
0^{\circ} 41.0^{\prime} \mathrm{E}\end{array}$ & W & $0-34$ & $\mathrm{PA}, \mathrm{SA}, \mathrm{PC}, \mathrm{CPU}$ \\
\hline & Columbrete Grande & $\begin{array}{r}39^{\circ} 53.8^{\prime} \mathrm{N} \\
0^{\circ} 41.4^{\prime} \mathrm{E}\end{array}$ & $\mathrm{E}$ & $5-30$ & $\mathrm{SA}, \mathrm{PC}, \mathrm{CPU}$ \\
\hline & Columbrete Grande & $\begin{array}{c}38^{\circ} 53.8^{\prime} \mathrm{N} \\
0^{\circ} \quad 4.4^{\prime} \mathrm{E}\end{array}$ & $\mathrm{SE}$ & $3-44$ & $\mathrm{SA}, \mathrm{PC}, \mathrm{CPU}, \mathrm{CPL}$ \\
\hline & Columbrete Grande & $\begin{array}{c}39^{\circ} 53.62^{\prime} \mathrm{N} \\
0^{\circ} \quad 4.20^{\prime} \mathrm{E}\end{array}$ & S & $18-42$ & $\mathrm{SA}, \mathrm{PC}, \mathrm{CPU}, \mathrm{CPL}$ \\
\hline & Placer Barra Alta & $\begin{array}{r}39^{\circ} 49.8^{\prime} \mathrm{N} \\
0^{\circ} 32.25^{\prime} \mathrm{E}\end{array}$ & Horizontal & $30-32$ & CPU, CPL, DB \\
\hline & Placer Barra Alta & $\begin{array}{c}39^{\circ} 49.9^{\prime} \mathrm{N} \\
0^{\circ} 32.20^{\prime} \mathrm{E}\end{array}$ & Horizontal & $36-40$ & CPU, CPL \\
\hline & La Foradada & $\begin{array}{r}39^{\circ} 52.4^{\prime} \mathrm{N} \\
0^{\circ} 39.2^{\prime} \mathrm{E}\end{array}$ & $-{ }^{a}$ & $9-20$ & $\mathrm{PA}, \mathrm{SA}, \mathrm{PC}, \mathrm{SOC}$ \\
\hline \multirow[t]{6}{*}{ Mallorca Is. } & Sa Dragonera & $\begin{array}{r}39^{\circ} 34.99^{\prime} \mathrm{N} \\
2^{\circ} 18.22^{\prime} \mathrm{E}\end{array}$ & $\mathrm{SE}$ & $3-54$ & PA, SA, PS, CBL, CBU \\
\hline & Sa Dragonera & $\begin{array}{r}39^{\circ} 34.99^{\prime} \mathrm{N} \\
2^{\circ} 18.22^{\prime} \mathrm{E}\end{array}$ & $\mathrm{S}$ & $3-40$ & SA, PC, UB \\
\hline & Formentor Cape & $\begin{array}{r}39^{\circ} 57.65^{\prime} \mathrm{N} \\
3^{\circ} 13.04^{\prime} \mathrm{E}\end{array}$ & NW & $3-38$ & $\mathrm{SA}, \mathrm{PC}, \mathrm{CBU}, \mathrm{CBL}$ \\
\hline & Formentor Is. & $\begin{array}{c}39^{\circ} 55.05^{\prime} \mathrm{N} \\
3^{\circ} 8.5^{\prime} \mathrm{E}\end{array}$ & NE & $3-15$ & PA, SA, SOC \\
\hline & Es Farayó & $\begin{array}{r}39^{\circ} 42.5^{\prime} \mathrm{N} \\
3^{\circ} 28.5^{\prime} \mathrm{E}\end{array}$ & - & $5-12$ & $\mathrm{SOC}$ \\
\hline & Catedral Cave & $\begin{array}{r}39^{\circ} 44.5^{\prime} \mathrm{N} \\
3^{\circ} 27.9^{\prime} \mathrm{E}\end{array}$ & NE & $12-9$ & $\mathrm{SOC}$ \\
\hline \multirow[t]{5}{*}{ Cabrera Is. } & Blava Cave & $\begin{array}{c}39^{\circ} \quad 9.61^{\prime} \mathrm{N} \\
2^{\circ} 56.5^{\prime} \mathrm{E}\end{array}$ & NW & $3-14$ & SOC \\
\hline & Estel de Dos Colls & $\begin{array}{rr}39^{\circ} & 7.4^{\prime} \mathrm{N} \\
2^{\circ} & 56.2^{\prime} \mathrm{E}\end{array}$ & $N$ & $3-40$ & PA, SA, PC, SOC \\
\hline & Calamars Cave & $\begin{array}{cc}39^{\circ} & 7.8^{\prime} \mathrm{N} \\
3^{\circ} & 54.4^{\prime} \mathrm{E}\end{array}$ & SW & $7-13$ & $\mathrm{SOC}$ \\
\hline & L'Olla & $\begin{array}{rr}39^{\circ} & 9.1^{\prime} \mathrm{N} \\
3^{\circ} & 5.8^{\prime} \mathrm{E}\end{array}$ & $E$ & $1-6$ & PM, PA, GSO \\
\hline & Sa Carbassa Cape & $\begin{array}{rr}39^{\circ} & 8.92^{\prime} \mathrm{E} \\
2^{\circ} & 58.17^{\prime} \mathrm{E}\end{array}$ & $E$ & $0-32$ & PA, SA, PC \\
\hline \multirow[t]{2}{*}{ Menorca Is } & Cavalleria Cape & $\begin{array}{rr}40^{\circ} & 5.75^{\prime} \mathrm{N} \\
4^{\circ} & 5.95^{\prime} \mathrm{E}\end{array}$ & NE & $3-30$ & $\mathrm{PA}, \mathrm{SA}, \mathrm{PC}, \mathrm{SOC}$ \\
\hline & Fornells Harbor & $\begin{aligned} 40^{\circ} & 3.33^{\prime} \mathrm{N} \\
3^{\circ} & 8.3^{\prime} \mathrm{E}\end{aligned}$ & - & $0.5-4$ & $E E L, U P, D B$ \\
\hline \multirow[t]{6}{*}{ Ibiza Is. } & Bledes Is. & $\begin{array}{c}38^{\circ} 59.9^{\prime} \mathrm{N} \\
1^{\circ} \quad 9.6^{\prime} \mathrm{E}\end{array}$ & $\mathrm{N}-\mathrm{NW}$ & $3-52$ & $\mathrm{SA}, \mathrm{PC}, \mathrm{CPU}, \mathrm{CPL}, \mathrm{DB}$ \\
\hline & Es Vedrà Is. & $\begin{array}{r}38^{\circ} 51.5^{\prime} \mathrm{N} \\
1^{\circ} 11.2^{\prime} \mathrm{E}\end{array}$ & $N-N W$ & $3-57$ & $\mathrm{SA}, \mathrm{PC}, \mathrm{CPU}, \mathrm{CPL}$ \\
\hline & Port Roig Cape & $\begin{array}{r}38^{\circ} 51.7^{\prime} \mathrm{N} \\
1^{\circ} 17.8^{\prime} \mathrm{E}\end{array}$ & $\mathrm{S}$ & $2-25$ & PA, SA, PC \\
\hline & Punta Pedrera/Torre Gavina & $\begin{array}{r}38^{\circ} 43.7^{\prime} \mathrm{N} \\
1^{\circ} 23.0^{\prime} \mathrm{E}\end{array}$ & Horizontal & $46-48$ & PM, DB \\
\hline & Conillera Is. & $\begin{array}{r}38^{\circ} 59.2^{\prime} \mathrm{N} \\
1^{\circ} 12.3^{\prime} \mathrm{E}\end{array}$ & W & $3-35$ & PA, PC, CBL, CBU \\
\hline & Margaritas Is. & $\begin{array}{rr}39^{\circ} & 2.7^{\prime} \mathrm{N} \\
1^{\circ} & 18.9^{\prime} \mathrm{E}\end{array}$ & SW & $3-40$ & $\mathrm{SA}, \mathrm{PC}, \mathrm{SOC}, \mathrm{DB}$ \\
\hline Formentera Is. & Estany des Peix & $\begin{array}{r}38^{\circ} 43.5^{\prime} \mathrm{N} \\
1^{\circ} 24.8^{\prime} \mathrm{E}\end{array}$ & - & $0.5-3$ & EEL, UB, DB \\
\hline
\end{tabular}




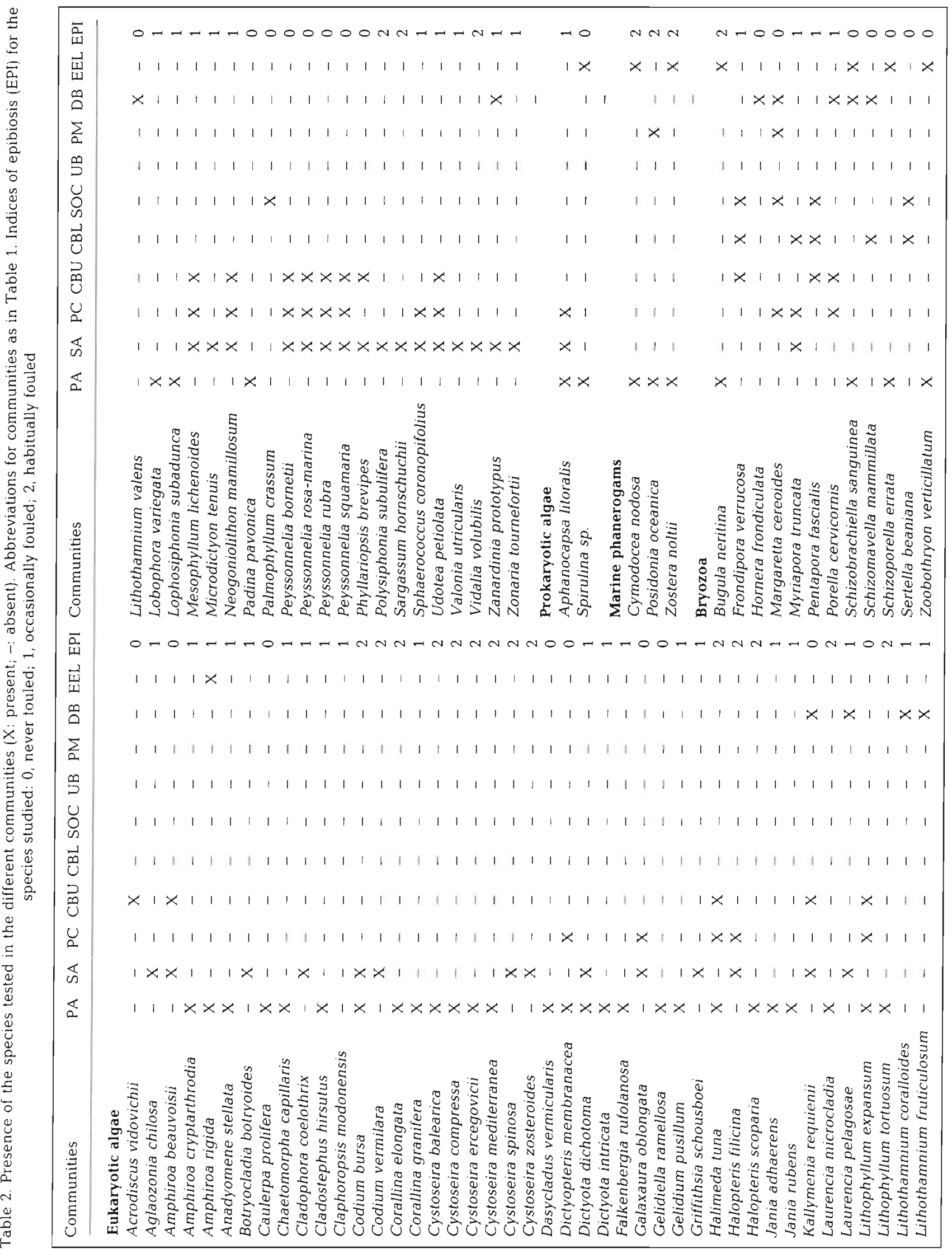




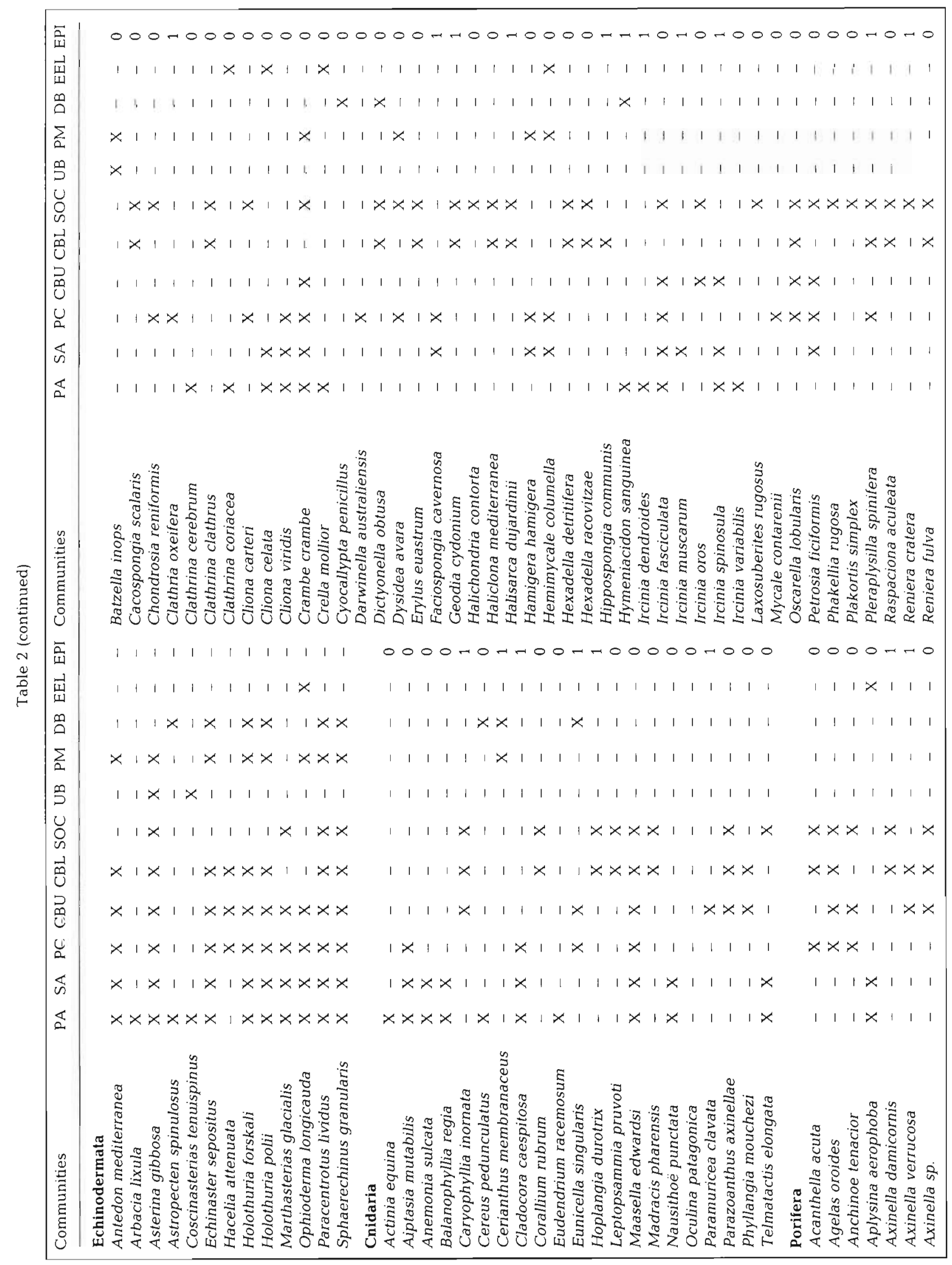




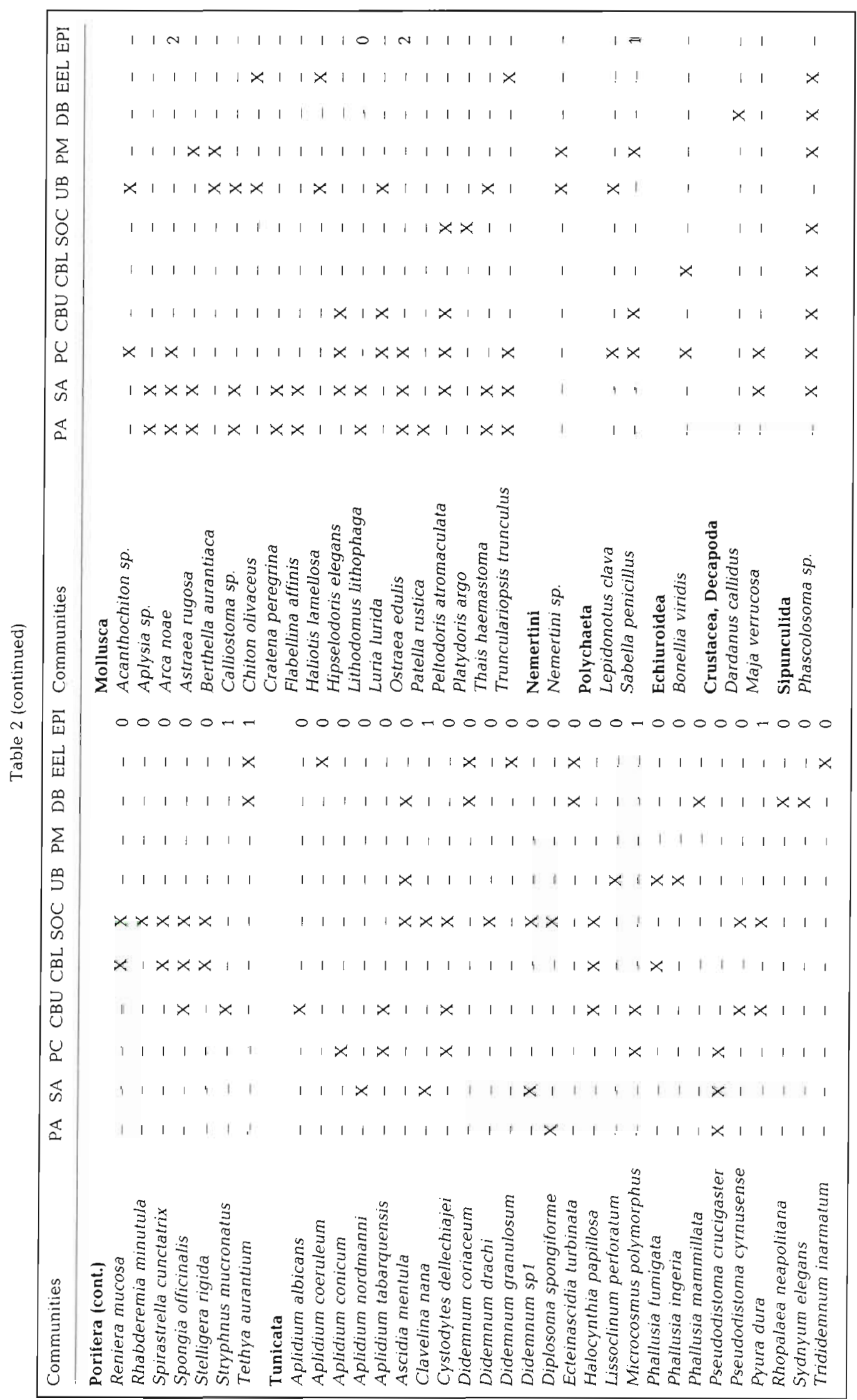


(HSV) cultured in kidney cells of monkey (CV-1) and with vesicular stomatitis virus (VSV) in kidney cells of hamster (BAK) as previously described (Schroeder et al. 1981). All activities (antimicrobial, antifungal, antimitotic and antiviral) were graded on 4 levels, from 0 (non-active) to 3 (very active). Although the tests were performed using non-marine organisms, good agreement might be expected between presence of activity in these tests and activity against marine organisms (Thompson et al. 1985, authors' current research).

Numerical methods. Correspondence analyses (Legendre \& Legendre 1979) were performed on an activities per species matrix to ascertain relationships between activities. In a further step, we added the values of epibiosis as a new variable in the matrix and repeated the analysis (soft vagile species were excluded in this latter analysis). The activity and epibiosis indices were transformed into percentages (Field et al. 1982) prior to the numerical analyses.

A cluster analysis was performed on the communities using as descriptors the 5 categories of antibiotic activity measured as percentage of species present which show activity (Table 3 ). The Canberra metrics and the

Table 3. Percentages of active species per community. MIT: antimitotic; CYT: cytotoxic; BACT: antibacterial; FUNG: antifungal; VIR: antiviral. Abbreviations for communities as in Table 1

\begin{tabular}{|lrrrrr|}
\hline \multirow{2}{*}{ Community } & \multicolumn{5}{c|}{$\begin{array}{c}\text { Activity } \\
\text { BACT }\end{array}$} \\
& MIT & CUNG & VIR \\
\hline PA & 51.190 & 48.810 & 10.465 & 4.651 & 23.810 \\
SA & 50.633 & 51.899 & 8.537 & 7.317 & 21.519 \\
PC & 63.492 & 63.492 & 12.308 & 18.462 & 25.397 \\
CBU & 65.517 & 60.345 & 16.667 & 15.000 & 29.310 \\
CBL & 69.565 & 67.391 & 34.783 & 25.000 & 30.435 \\
SOC & 75.000 & 71.667 & 31.250 & 17.188 & 30.000 \\
UB & 53.333 & 60.000 & 5.882 & 11.765 & 6.667 \\
PM & 40.909 & 68.182 & 9.524 & 19.048 & 9.091 \\
DB & 41.935 & 51.613 & 5.882 & 2.941 & 9.677 \\
EEL & 65.385 & 34.615 & 11.538 & 3.846 & 26.923 \\
& & & & & \\
\hline
\end{tabular}

aggregation algorithm UPGMA. (Legendre \& Legendre 1979) were used.

Both cluster and correspondence analyses were carried out using Fortran programs kindly placed at our disposal by Dr J. Lleonart from the Institut de Ciències del Mar in Barcelona.

The dependence/independence between activities and taxonomic groups, as well as that between activities and communities, was established by means of the $G$ statistic for an $\mathrm{R} \times \mathrm{C}$ contingency table (Sokal \& Rohlf 1979).

\section{RESULTS}

\section{Activity and taxonomy}

The chemical bioactivity varied according to main taxonomic group, the most active taxa being Porifera, Bryozoa and Tunicata (Fig. 1).

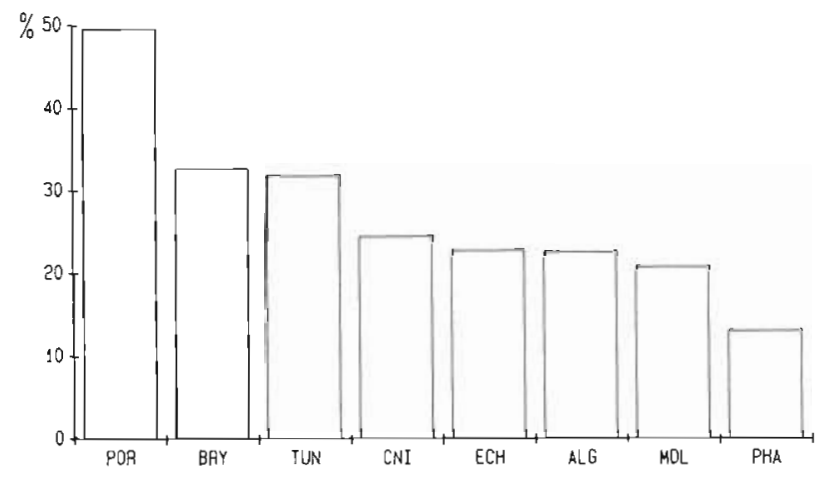

Fig. 1. Mean percentages of active species for all activities tested in the 8 taxonomic groups. Percentages dependent on taxonomic group at a level of significance of 0.1 (G-test). POR: Porifera; BRY: Bryozoa; TUN: Tunicata; CNI: Cnidaria; ECH: Echinodermata; ALG: Algae; MOL: Mollusca; PHA: Phanerogamia

Antimitotic, cytotoxic, antibacterial and antifungal activities were differentially distributed among the taxa. Antimitotic activity was the most remarkable feature in Porifera and Bryozoa, whereas cytotoxic activity was noteworthy in Porifera, Tunicata, Cnidaria and Echinodermata. Antibacterial and antifungal activities were widespread only in sponges. Antiviral activity was quite uniformly distributed among taxa, with a slightly higher incidence in Bryozoa, Porifera, Tunicata and Cnidaria (Fig. 2).

A significant dependence on taxonomic group was only found for the following levels of activity: antibacterial 1, antiviral 3 , antimitotic 1, and cy totoxic 2 and 3 (Fig. 3).

\section{Relationships between activities}

It appears from the spatial ordination of the activities obtained from the correspondence analyses (Fig. 4) that there is a close association between antimitotic and cytotoxic activities, as well as between antibacterial and antifungal ones, the two being separated on the second factorial axis. These 2 pairs of activities appear in the negative sector of the first axis, whereas antiviral activity lies in the positive sector far from the remaining activities.

A group of Porifera and Algae is correlated with the antifungal and antibacterial activities, while some 

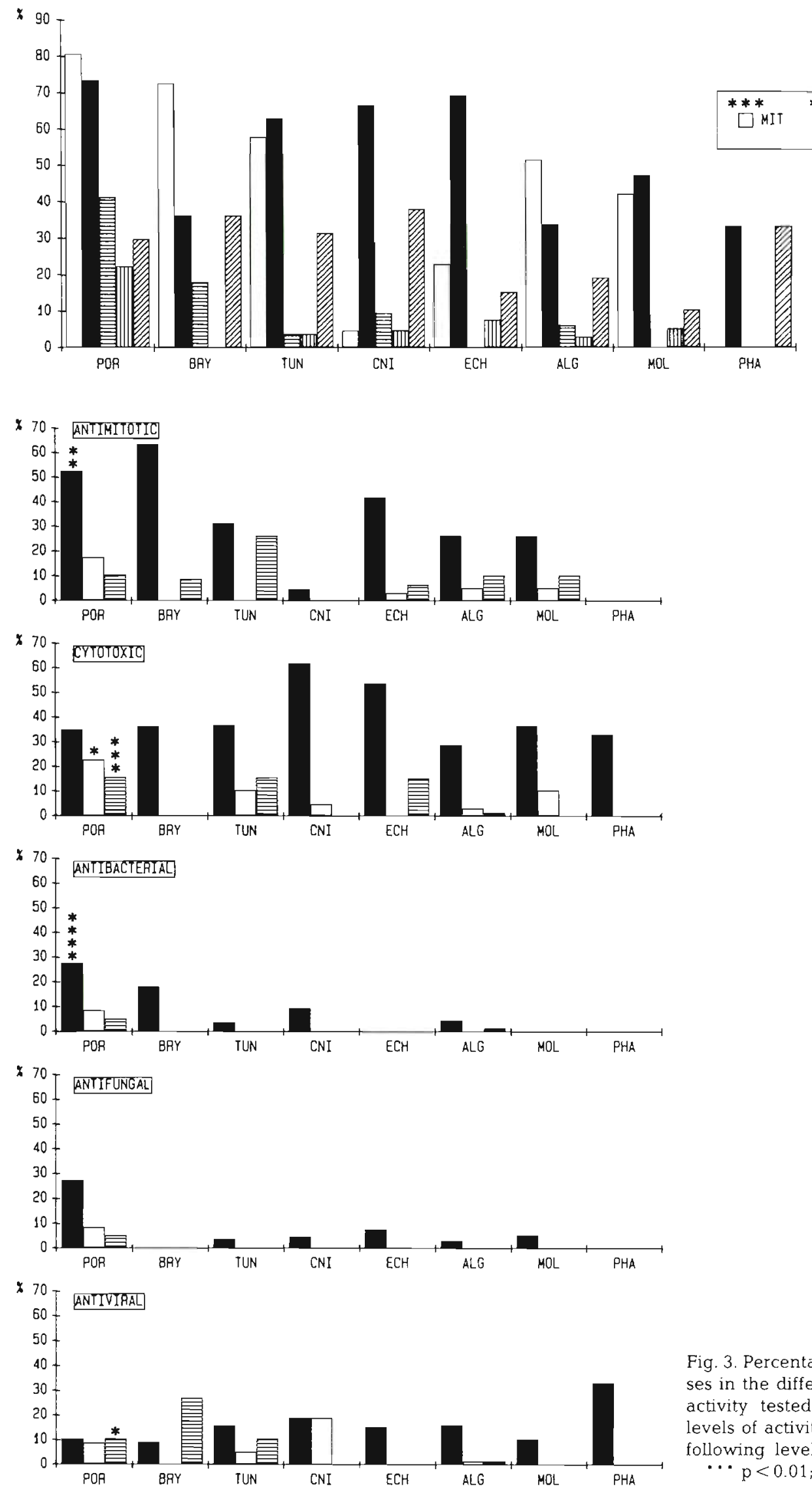

Fig. 2. Percentages of active species (sum of species with level 1, 2 and 3) in the taxonomic groups studied. Abbreviations as Fig. 1. Some activities are dependent on taxon at the following levels of significance: $\cdots \quad \mathrm{p}<0.001 ; \quad \cdots \quad \mathrm{p}<0.005$ $\cdot \mathrm{p}<0.025$ (G-test)

ACT-1 $\square$ ACT-2 目 ACT-3

Fig. 3. Percentages of the 3 levels of active responses in the different taxa studied, for each type of activity tested. Abbreviations as Fig. 1. Some levels of activities are dependent on taxon at the following levels of significance: $\cdots p<0.001$; $\cdots p<0.01 ; \cdots p<0.025 ; \cdot p<0.05$ (G-test) 


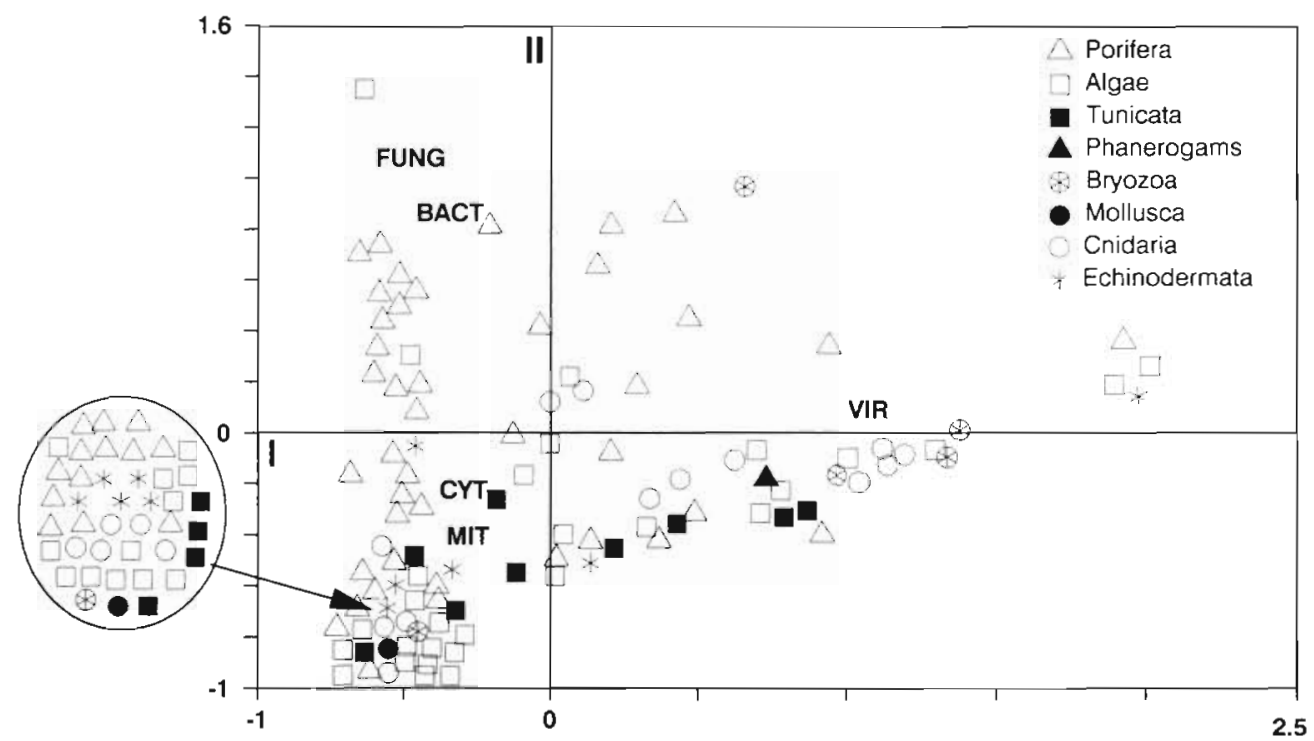

Fig. 4. Spatial representation of the correspondence analysis on a species-activities matrix. MIT: antimitotic; CYT: cytotoxic; BACT: antibacterial; FUNG: antifungal; VIR: antiviral

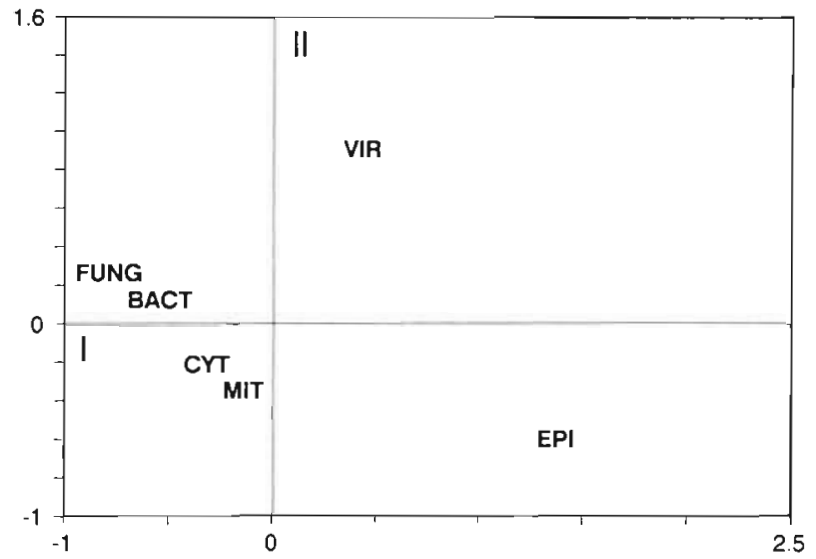

Fig. 5. Spatial representation of the activities (abbreviations as Fig. 4) and epibiosis (EPI) obtained from the first 2 axes generated by the correspondence analysis

Cnidaria, Algae and Bryozoa are mainly responsible for the position of antiviral activity in the spatial representation. Representatives of all the taxonomic groups appear close to the cytotoxic and antimitotic activities.

\section{Activity versus epibiosis}

The frequency with which the species sampled bear fouling organisms (epibionts) is shown in Table 2.

The introduction of epibiosis indices as a new variable in the ordination analysis (Fig. 5) causes a redistribution of the variables along the components: the first axis (33.94\% of variance explained) is now defined by the variable epibiosis, which appears in the positive sector, opposite to the antimitotic-cytotoxic and antibacterial-antifungal pairs of activities. The second component (23.44\% of variance) maintains approximately the relationships between activities shown in the previous correspondence analyses (Fig. 4). Antiviral activity now features an intermediate position, far from either the other activities or the epibiosis variable.

\section{Activity and communities}

Most of the resulting biological activities exhibit clear relationships with structural and dynamic charac-

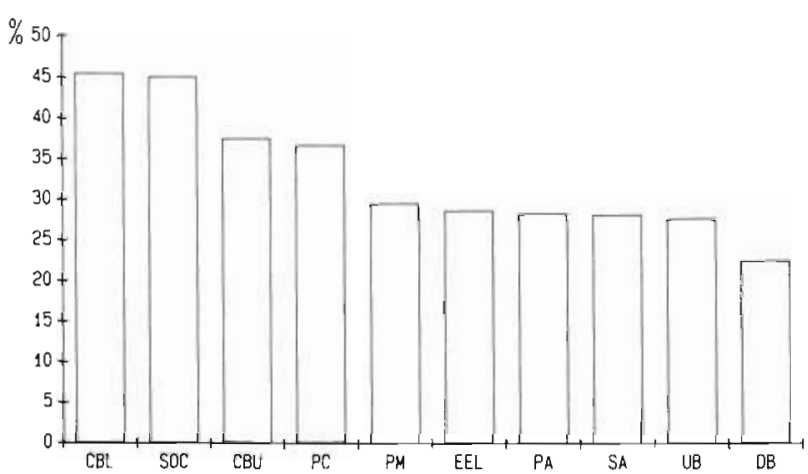

Fig. 6. Mean percentages of active species for all activities tested in each community studied. Percentages dependent on community at a significance level of $\mathrm{p}<0.5$ (G-test). PA: photophilic algae; SA: sciaphilic algae; PC: precoralligenous; CBU: coralligenous blocks, upper sides; CBL: coralligenous blocks, lower sides; SOC: semi-obscure caves; UB: under blocks; PM: Posidonia meadows; DB: detritic bottoms; EEL: euryhaline and eurythermal lagoons 

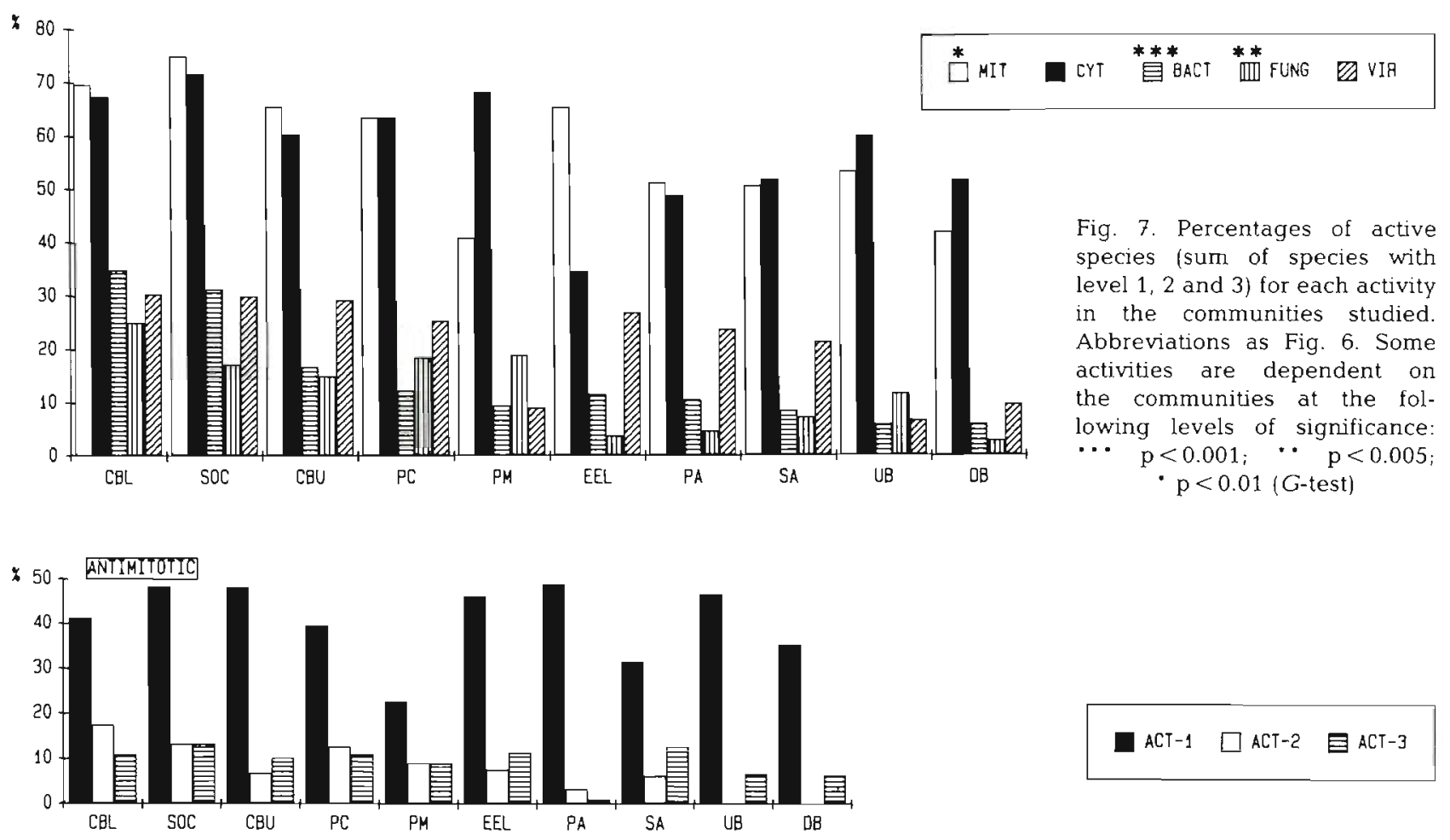

ACT-1 $\square$ ACT-2 目 ACT-3
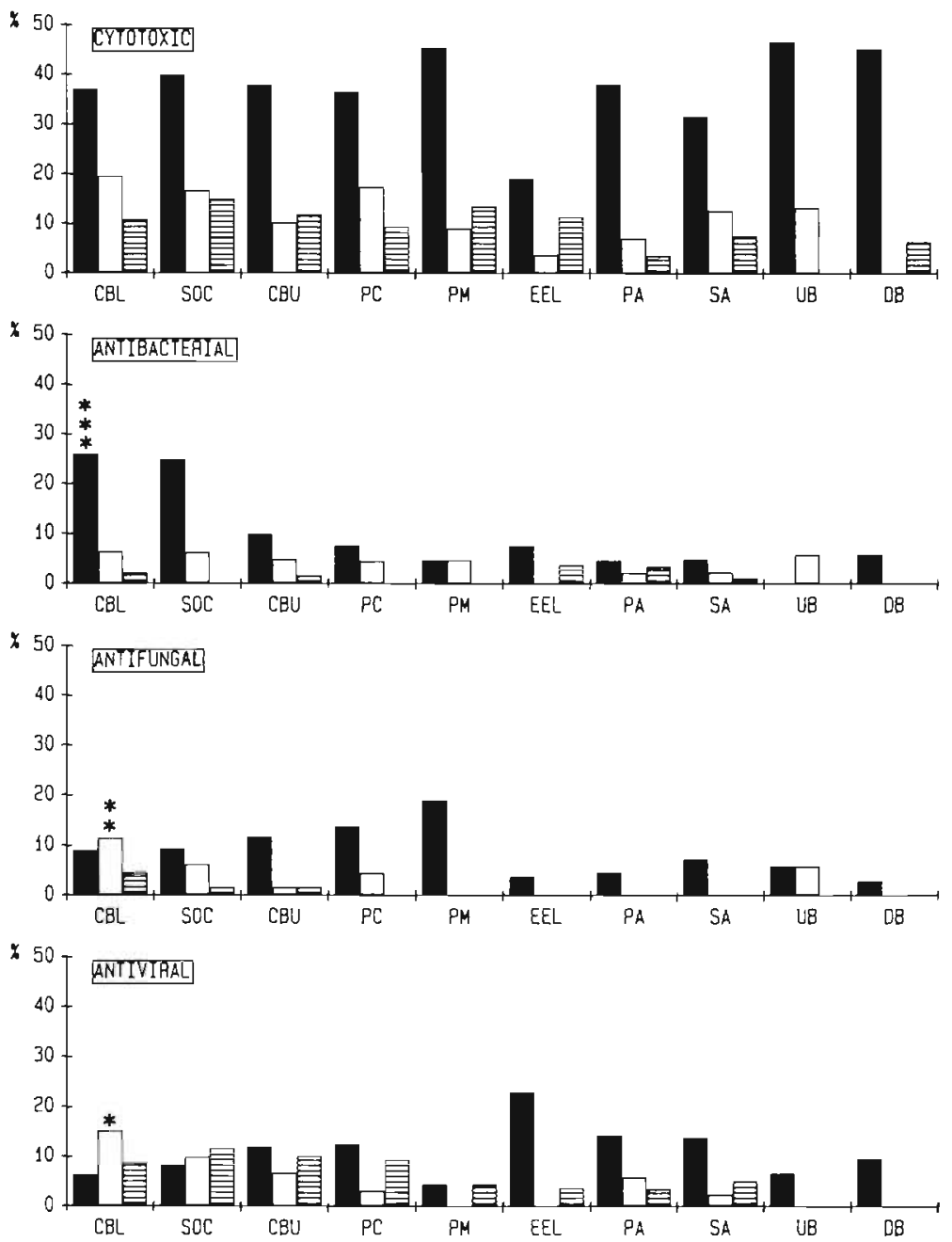

Fig. 8. Percentages of the 3 levels of activity in the communities studied, analyzed separately for each activity tested. Abbreviations as Fig. 6. Some levels of activity are dependent on the communities at the following levels of significance $\cdots p<0.001 ;{ }^{\cdots} p<0.005 ;{ }^{\circ} p<0.025$ (G-test) 


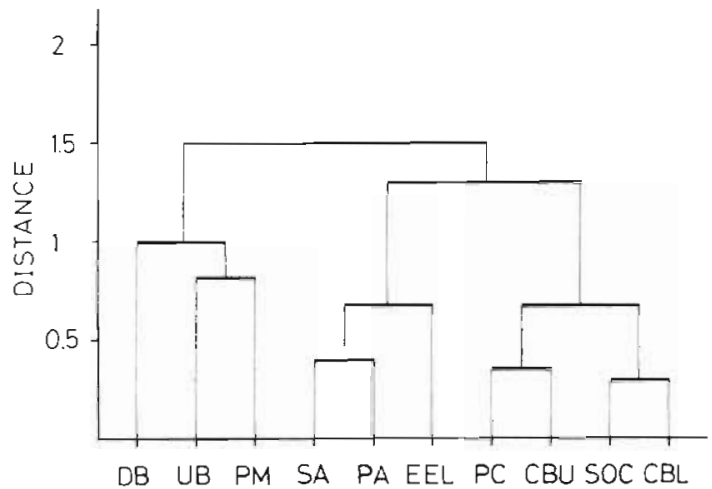

Fig. 9. Cluster analysis of the communities, using the percentage of species present which are active (for one or more of the activities tested) as descriptors. Abbreviations as Fig. 6

teristics of the benthic communities. The mean percentage of active species is slightly dependent on the communities treated (Fig. 6). Active species are in general much more abundant in sciaphilic/cryptic habitats (CBL and SOC) (Fig. 6) where filter-feeder, surface-dependent invertebrates dominate (Ros et al. 1985). A significantly higher percentage of active species (significance level: $p<0.005$ ) was found in these communities in comparison with those from more photophilic environments (PA, SA EEL, PM). The bioactivity reached its lowest values in detritic communities (DB) (Fig. 6). The differences found among the photophilic communities are in general slight except for the Posidonia meadows which show a high percentage of species containing cytotoxic molecules. The variance which does occur in these photophilic habitats depends on the type of activity (Fig. 7).

On the whole, cytotoxic and antimitotic activities are the most abundant $(38.6$ and $39.8 \%$ of active species respectively), and are widespread in all the communities explored (Fig. 7).

The contingency tables between activities and communities indicate that the distribution of antibacterial and antifungal activities is strongly dependent on the type of community studied (at significance levels $\mathrm{p}<$ 0.001 and $\mathrm{p}<0.005$, respectively). Both activities can be clearly related to sciaphilic communities $(\mathrm{CBL}, \mathrm{CBU}$, $\mathrm{SOC}$ and $\mathrm{PC}$. Antimitotic activity is also distributed differentially among the different communities (significance level: $p<0.01$ ). Cytotoxic and antiviral activities are not dependent on the community considered (Fig. 7).

A significant dependence on community was only found for the following levels of activity: antibacterial 1 , antiviral 2, and antifungal 2 (Fig. 8).

The distances between communities are represented by means of a dendrogram (Fig. 9), using as descriptors the 5 categories of activities measured as percentages of species present which show activity.
Three clusters of communities are clearly separated at a distance of 1.1 .

The first group, formed by 2 subgroups, includes the sciaphilic and semi-sciaphilic communities (CBL, SOC, $\mathrm{CBU}$ and $\mathrm{PC}$ ) and contains the highest number of active species. The second group corresponds to the euryhaline and eurytherm lagoons and to the more photophilic communities (PA and SA). The last group is formed by the communities with the lowest percentages of active species: the soft bottom and under-block communities (PM, DB, UB). This analysis supports the view that there is a coupling between bioactivity and rocky sciaphilic communities.

\section{DISCUSSION AND CONCLUSIONS}

There are clear relationships between activities and taxonomic groups. Porifera, Bryozoa and Tunicata are on the whole the most active taxa. They form a large

Table 4. Percentages of species with different levels of activity featuring any of the 3 indices of epibioses. Indices of epibiosis as Table 1. Abbreviations for activities as Table 3

\begin{tabular}{|c|c|c|c|c|}
\hline \multicolumn{5}{|c|}{ Epibionts } \\
\hline & 0 & 1 & 2 & Totals \\
\hline \multicolumn{5}{|l|}{ MIT } \\
\hline 0 & 14.61 & 14.04 & 7.30 & 35.96 \\
\hline 1 & 27.53 & 14.04 & 3.93 & 45.51 \\
\hline 2 & 5.62 & 2.81 & 0.00 & 8.43 \\
\hline 3 & 6.74 & 2.25 & 1.12 & 10.11 \\
\hline Totals & 54.49 & 33.15 & 12.36 & 100.00 \\
\hline \multicolumn{5}{|l|}{ CYT } \\
\hline 0 & 19.05 & 13.10 & 10.71 & 42.86 \\
\hline 1 & 23.81 & 12.50 & 2.38 & 38.69 \\
\hline 2 & 8.33 & 2.38 & 0.00 & 10.71 \\
\hline 3 & 6.55 & 1.19 & 0.00 & 7.74 \\
\hline Totals & 57.74 & 29.17 & 13.10 & 100.00 \\
\hline \multicolumn{5}{|l|}{ BACT } \\
\hline 0 & 43.92 & 26.46 & 12.17 & 82.54 \\
\hline 1 & 9.52 & 3.17 & 0.00 & 12.70 \\
\hline 2 & 1.59 & 1.06 & 0.00 & 2.65 \\
\hline 3 & 1.06 & 1.06 & 0.00 & 2.12 \\
\hline Totals & 56.08 & 31.75 & 12.17 & 100.00 \\
\hline \multicolumn{5}{|l|}{ FUNG } \\
\hline 0 & 49.21 & 29.63 & 12.17 & 91.01 \\
\hline 1 & 4.76 & 1.06 & 0.00 & 5.82 \\
\hline 2 & 1.59 & 0.53 & 0.00 & 2.12 \\
\hline 3 & 0.53 & 0.53 & 0.00 & 1.06 \\
\hline Totals & 56.08 & 31.75 & 12.17 & 100.00 \\
\hline \multicolumn{5}{|l|}{ VIR } \\
\hline 0 & 38.76 & 24.16 & 9.55 & 72.47 \\
\hline 1 & 7.30 & 5.06 & 1.69 & 14.04 \\
\hline 2 & 3.93 & 1.69 & 0.56 & 6.18 \\
\hline 3 & 4.49 & 2.25 & 0.56 & 7.30 \\
\hline Totals & 54.49 & 33.15 & 12.36 & 100.00 \\
\hline
\end{tabular}


part of the biomass of the sciaphilic/cryptic communities and are therefore responsible for the high activity rates found there. The same taxa have demonstrated high levels of activity in other latitudes (Munro et al. 1989).

As regards the high antibacterial activity in the Porifera, note that symbiotic bacteria, present in many sponge species (Vacelet 1970, Vacelet \& Donadey 1977), may account in some cases for the activity found.

A close association was found between antibacterial and antifungal, as well as between cytotoxic and antimitotic, activities. Antiviral activity does not show preferential association with any of the other activities. This pattern seems to indicate 2 different chemically based strategies in benthic organisms: those displaying antibacterial-antifungal activities, and those featuring cytotoxic-antimitotic ones.

The relationships between activities and epibiosis should be carefully considered. A general interpretation of the possible antifouling role of chemical bioactivity should take into account other mechanisms protecting organisms against epibiosis effects which can overlap with those of allelochemicals, e.g. loss of superficial cells in calcareous algae (Johnson \& Mann 1986), or acid pH and toxic metals in tunicates (Stoecker 1979) and algae (Baker \& Orr 1986).

Antibacterial and antifungal activities seem to play a general antifouling role as no habitual epibiosis (index 2) occurs whenever any level of either activity is displayed (Table 4). In theory they could prevent the establishment of bacterial films which are believed to be a necessary first step in succession, enabling the settlement of invertebrate larvae (Shim \& Jurng 1987. Wahl 1989). A positive correlation between antimicrobial activity and absence of epibiosis has also been reported for sponges (Amade et al. 1987) and algae (AlOgily \& Knight-Jones 1977)

As far as antifouling defences are concerned, cytotoxic and antimitotic activities seem to be less effective than antibacterial and antifungal ones: a relatively high number of species possessing cytotoxic and antimitotic activities were fouled (16.1 and 19.0\%, respectively) (Table 4 ).

The data on activities on species from euryhaline and eurythermal lagoons (EEL) are difficult to interpret. These zones constitute a complex of different habitats that are poorly represented in our samples (Table 1) and require more complete studies.

According to the results obtained, species with bioactive chemicals in the western Mediterranean are significantly more widespread in sciaphilic/cryptic communities (lower side of the coralligenous blocks and semi-dark caves and overhangs) than in photophilic ones. The high incidence of species with cytotoxic molecules in the photophilic community of Posidonia meadows could be influenced by the fauna associated with the rhizome of the plant which is rather sciaphilic (Ros et al. 1985).

Mediterranean sciaphilic communities are characterized by high species diversity, animal dominance (mainly filter-feeding, substratum-dependent invertebrates), low levels of predation and disturbance (compared to photophilic communities), low growth rates (relative to shallower zones), a tendency to build up lasting structures (skeletons), and strong space competition as the substratum is limiting (Zabala \& Ballesteros 1989). Any investment in chemical production may play an important role in space competition in these communities.

Finally, chemical defences do not seem to appear preferentially in organisms lacking other types of defences (i.e. spicules or exoskeletons), as has been asserted for sponges from other latitudes (Faulkner \& Ghiselin 1983). Our concepts of economical behavior are not always applicable to nature: the protection and survival of a species can be assured simultaneously by different mechanisms, even if the cost of that protection results in a loss of relative growth rate (Hay 1989).

Acknowledgements. Many people collaborated in making this study possible. Dr K. Rinehart Jr was the head of the PharmaMar-I expedition. He and Mr M. Echenique, Mr A Gomez Dr R. Brusca, Dr J. M. Tur, and Ms D. Rosell took part in the field work. Ms M. García and Ms R. Lopez participated in the screening, and together with Ms M. Bardaji, recorded the data on computer files. Ms D. Rosell, Dr J. M. Tur, Mr V. Alvà, Dr J. M. Gili, Dr M. Zabala and Dr M. Ballesteros identified some specimens and gave information on species distribution. The crew of the BO 'Garcia del Cid' provided technical assistance during the survey. Finally Drs J. Vacelet, N. Boury-Esnault, M. Pansini and S. Pomponi kindly commented on the manuscript. To all of these our sincere acknowledgement. Special thanks are given to the anonymous reviewers, whose constructive comments notably improved the manuscript. This study was carried out under the ECOFARM project sponsored by PharmaMar S. A. Madrid.

\section{LITERATURE CITED}

Al-Ogily, S. M., Knight-Jones, E. W. (1977). Antifouling role of antibiotics produced by marine algae and bryozoans. Nature, Lond. 265: 728-729

Amade, P., Charroin, G., Baby, C., Vacelet, J. (1987). Antimicrobial activities of marine sponges from the Mediterranean Sea. Mar. Biol. 94: 271-275

Baker, J. H., Orr, D. R. (1986). Distribution of epiphytic bacteria on fresh water plants. J. Ecol. 74: 155-165

Bakus, G. J. (1974). Toxicity in holothurians: a geographic pattern. Biotropica 6: 229-236

Bakus, G. J. (1981). Chemical defense mechanisms on the Great Barrier Reef, Australia. Science 211: 497-499

Bakus, G. J., Green, G. (1974). Toxicity in sponges and holothurians: a geographic pattern. Science 185: 951-953

Bakus, G. J., Target, N. M., Schulte, B. (1986). Chemical 
ecology of marine organisms: an overview. J. chem. Ecol. 12 (5): 951-987

Ballesteros, E. (1984). Els vegetals i la zonació litoral: espècies, comunitats i factors que influeixen en la seva distribució $\mathrm{Ph}$. D. thesis, University of Barcelona

Ballesteros, E., García, A., Lobo, A., Romero, J. (1984). L'alguer de Posidonia oceanica de les Illes Medes. In: Ros, J., Olivella, J., Gili, J. M. (eds.) Els sistemes naturals de les Illes Medes. Arx. Secc. Ciències I.E.C. 73: 739-759

Bergquist, P. R. (1979). Sponge chemistry: a review. Colloques int. Cent. natn. Rech. Scient. 291: 383-392

Bergquist, P. R., Bedford, J. J. (1978). The incidence of antibacterial activity in marine Demospongiae; systematic and geographic considerations. Mar. Biol. 46: 215-221

Bergquist, P. R., Lawson, M. P., Lavis, A., Cambie, R. C. (1984). Fatty acid composition and the classification of the porifera. Biochem. Syst. Ecol. 13: 63-84

Bergquist, P. R., Wells, R. J. (1983). Chemotaxonomy of the Porifera: the development and current status of the field. In: Scheuer, P. J. (eds.) Marine natural products, Vol. 5. Academic Press, New York, p. 1-50

Buss, L. W. (1976). Better living through chemistry: the relationships between allelochemical interactions and competitive networks. In: Harrison, F. W., Cowden, R. R. (eds.) Aspects on sponge biology, Academic Press, New York, p. 315-327

Castiello, D., Cimino, G., De Rosa, S., De Stefano, S., Izzo, G., Sodano, G. (1979). Studies on the chemistry of the relationships between the opistobranch Peltodoris atromaculata and the sponge Petrosia ficiformis. Colloques int. Cent. natn. Rech. Scient. 291: 413-422

Cimino, G., De Stefano, S., Minale, L., Sodano, G. (1975). Metabolism in Porifera. III. Chemical patterns and the classification of the Demospongiae. Comp. Biochem. Physiol. 50 (B): 279-285

Coll, J. C., La Barre, S., Sammarco, P. W., Williams, W T., Bakus, G. J. (1982). Chemical defenses in soft corals (Coelenterata:Octocorallia) of the Great Barrier Reef: a study of comparative toxicities. Mar. Ecol. Prog. Ser. 8: 271-278

Faulkner, D. J., Ghiselin, M. T (1983). Chemical defense and evolutionary ecology of dorid nudibranchs and some other opistobranch gastropods. Mar. Ecol. Prog. Ser. 13: 295-301

Fenical, W., Norris, J. N. (1975). Chemotaxonomy in marine algae: chemical separation of some Laurencia species (Rhodophyta) from the Gulf of California. J. Physiol. 11: 104-108

Field, J. G., Clarke, K. R., Warwick, R. M. (1982). A practical strategy for analysing multispecies distribution patterns. Mar. Ecol. Prog. Ser. 8: 37-52

Gili, J. M., Ros, J. (1985). Study and cartography of the benthic communities of Medes Islands (NE of Spain). P.S.Z.N.I.: Mar. Ecol. 6 (3): 219-238

Goodbody, I. (1961). Inhibition of the development of a marine sessile community. Nature, Lond. 190: 282-283

Green, G. (1977). Ecology of toxicity in marine sponges. Mar. Biol. 40: 207-215

Hay, M. K. (1984). Predictable spatial scapes from herbivory: how do these affect the evolution of herbivore resistence in tropical marine communities. Oecologia 64: 396-407

Hay, M. K. (1988). Marine plant-herbivore interactions: the ecology of chemical defense. Ann. Rev. Ecol. Syst. 19: 111-145

Hay, M. K. (1989). Anti-herbivory chemical defense in plants: a note on the concept of cost. Am. Nat. 133 (2): 281-287

Jackson, J. B. C., Buss, L. (1975). Allelopathy and spatial competition among coral reef invertebrates (species interactions, community structure). Proc. natn. Acad. Sci. USA 72: 5160-5163
Johnson, C. R., Mann, K. H. (1986). The crustose coralline alga, Phymatolithon Foslie, inhibits the overgrowth of seaweeds without relaying on herbivores. J. exp. mar. Biol Ecol. 96: 127-146

Lee, W. L., Gilchrist, B. M. (1985). Carotenoid patterns in twenty-nine species of sponges in the order Poecilosclerida (Porifera: Demospongiae): a possible tool for chemosystematics. Mar. Biol. 86: 21-35

Legendre, L., Legendre, P. (1979). Ecologie numérique. I. Le traitement multiple des données écologiques. II. La structure des données écologiques. Masson, Paris

McClintock, J. B. (1987). Investigation of the relationships between invertebrate predation and biochemical composition, energy content, spicule armament and toxicity of benthic sponges at McMurdo Sound, Anctartica. Mar. Biol. 94: $479-487$

Munro, M. H. G., Blunt, J. W., Barns, G., Battershill, C. N., Lake, R. S., Perry, N. B. (1989). Biological activity in New Zealand marine organisms. Pure appl. Chem. 61 (3): 529-534

Paul, V. J., van Alstyne, K. L. (1988). Use of ingested algal diterpenoids by Elisia halimedae Macnae (Opistobranchia:Ascoglossa) as antipredator defenses. J. exp. mar. Biol. Ecol. 119: 15-29

Pimentel, D. (1988). Herbivore population feeding pressure on plant host: feedback evolution and host conservation. Oikos 53: 289-302

Pérès, J. M., Picard, J. (1964). Nouveau manuel de bionomie benthique de la mer Méditerranée. Recl. Trav. Stn mar. Endoume 31 (74): 5-137

Porter, J. W., Targett, N. M. (1988). Allelochemical interactions between sponges and corals. Biol. Bull. mar. biol. Lab., Woods Hole 175: 230-239

Rinehart, K. L. Jr, Gloer, J. B. Jr, Wilson, G. R., Hughes, R. G. Jr, Li, H. L., Renis, H. E., McGovren, J. P. (1983). Antiviral and antitumor compounds from tunicates. Marine pharmacology: drugs from the sea. Fed. Proc. 42 (1): 87-90

Ros, J., Romero, J. Ballesteros, E., Gili, J. M. (1984). Diving in blue water The benthos. In: Margalef, R. (ed.) Western Mediterranean. Pergamon Press, Oxford, p. 233-295

Sammarco, P. W., Coll, J. C., La Barre, S., Willis, B. (1983) Competitive strategies of soft corals (Coelentereata Octocorallia): allelopathic effects on select scleractinian corals. Coral Reefs 1: 173-178

Sammarco, P. W. Coll, J. C., La Barre, S. (1985). Competitive strategies of soft corals (Coelentereata:Octocorallia). II. Variable defensive responses and stability to scleractinian corals. J. exp. mar. Biol. Ecol. 91: 199-215

Schroeder, A. C., Hughes, R. G. Jr, Block, A. (1981). Synthesis and biological effects of acyclic pyrimidine nucleoside analogues. J. med. Chem. 24: 1078-1083

Shanks, A. L., Graham, W M. (1988). Chemical defense in a scyphomedusa. Mar. Ecol. Prog. Ser. 45: 81-86

Sheppard, C. R. C. (1979). Interspecific aggression between coral reefs with reference to their distribution. Mar. Ecol. Prog. Ser 1: 237-247

Shim, J. M., Jurng, M. S. (1987). Development and succession of marine fouling organisms on artificial substrata. J. Oceanol. Soc. Korea 24 (4): 257-270

Sokal, R. R., Rohlf, F. J. (1979). Biometría. H. Blume, Madrid

Stoecker, D. (1978). Resistance of a tunicate to fouling. Biol Bull. mar. biol. Lab., Woods Hole 155: 615-626

Stoecker, D. (1980). Chemical defenses of ascidians against predators. Ecology 61 (6): 1327-1337

Thompson, J. E., Walker, R. P., Faulkner, J. (1985). Screening and bioassays for biologically-active substances from forty marine sponge species from San Diego, California, USA. Mar Biol. 88: 11-21 
Thompson, T E. (1960a). Defensive adaptation in Opistobranchs. J. mar. biol. Ass. U.K. 39: 123-134

Thompson, T. E. (1960b). Defensive acid-secretion in marine gastropods. J. mar. biol. Ass. U.K. 39: 112-115

Vacelet, J. (1970\}. Description de cellules à bactéries intranucleaires chez des éponges Verongia. J. Microsc. 9 (3): 333-346

Vacelet, J., Donadey, C. (1977). Electron microscope study of

This article was submitted to the editor the association between some sponges and bacteria. J. exp. mar Biol. Ecol. 30: 301-314

Wahl, M. (1989). Marine epibioses. I. Fouling and antifouling: some basic aspects. Mar. Ecol. Prog. Ser. 58: 175-189

Zabala, M., Ballesteros, E. (1989). Surface dependent strategies and energy flux in benthic marine communities or why corals do not exist in the Mediterranean. Scientia Marina $53(1): 3-17$

Manuscript first received: April 2, 1990

Revised version accepted: December 12, 1990 